современного общества относительно услуг переводчика, в частности для групп мигрантов. Определены ориентиры имиджевого подхода подготовки будущих переводчиков в высших учебных заведениях.

Ключевые слова: филолог, переводчик, имидж, глобализация, рынок труда, профессия, услуги.

REZVAN O., ILIENKOO. The problem of image perception of the profession of philologist in international discourse.

The topicality of the problem of image approach to the professional activities of future translators is proved in the article. The components of the personal image of the translator are identified: objective external and physiological properties of the personality (voice and related speech instruments: the pitch of the voice, the tempo of speech; physiognomy, facial expressions, movements); behavioral characteristics (manner and style of speech, style of clothing, walking); social and professional characteristics (education, social status, profession); self-perception in the profession; perception by reference groups; public image created by mediators (target groups which the translator communicates with). The dynamics of the content components for the concept "image of the translator" in modern conditions of the labor market is investigated. The influence of globalization processes of the world economy on the image of the translator is proved, in particular, the need to work in the conditions of the gig economy. The need for translators' virtual mobility is emphasized through an active use of electronic professional networking platforms, for instance, Linkedin. The importance of responding promptly to modern society's requests for translation services, in particular for migrant groups, is registered. The guidelines for the image approach of preparation of future translators at higher education institutions are defined and the specific tasks for supplementing the content of the academic training due to the professional standard 035 "Philology" are outlined. services.

Keywords: philologist, translator, interpreter, image, globalization, labor market, profession,

DOI: https://doi.org/10.31392/NZ-npu-145.2019.20

УДК 027.1:929

Савенкова Л. В., Торлін І. Г.

\title{
ПРИВАТНА БІБЛІОТЕКА ВЧЕНОГО ЯК ДОДАТКОВЕ ДЖЕРЕЛО ВІДТВОРЕННЯ ЙОГО ТВОРЧОЇ БІОГРАФІї
}

Дослідження наукової спадщини науковиів є важливою складової вивчення історії будьякого університету. У підготовленому матеріалі представлені результати дослідження особистого зібрання відомого фізика, професора, очільника кафедри фізики Київського педагогічного інституту імені М. Горького з 1934 до 1947 року Г. Г. Де-Метияа, які дозволяють відстежсити наукові зв'зки вченого у першій половині 20-го століття.

Ключові слова: дослідження, джерела, наука, історія, життєвий шлях.

Документальні джерела $є$ важливою базою для наукових досліджень у будь якій науковій галузі. Вивчення культурних та наукових досягнень кожної країни змушує звертатись до книжкових пам'яток, серед яких вагомою 
складовою є приватні книжкові колекції. Книги, що входять до складу таких зібрань, $€$ не лише предметом колекціонування та способом отримання інформації, але й засобом самоосвіти власників приватних книжкових колекцій [4]. Як правило, такі колекції рано чи пізно стають надбанням людства, вливаючись у фонди бібліотек. Кожна бібліотека світу має за честь зберігати приватні колекції видатних людей, подаровані ними особисто або їхніми рідними.

Для розуміння масштабу постаті вченого в історії науки потрібна низка складових, як от: відтворення життєвого шляху особи, аналіз наукової і викладацької діяльності, спогади колег і студентів, відтворення реалій епохи, і... перелік книг його приватної бібліотеки.

Вчений і педагог, про якого йдеться у цій статті, добре відомий науковому загалу як видатний фрізик, методист, організатор науки. Зважуючи на непросту епоху, йому було даровано доволі довге життя (народився у 1861, пішов 3 життя 1947 р.), яке він без останку присвятив улюбленій науці і викладанню.

Син бельгійського інженера і комерсанта, Георгій Георгійович Де-Метц по закінченню Новоросійського університету в Одесі готувався до професорського звання з фрізики у Страсбурзькому університеті. У 1889 році захистив магістерську, а у 1891 - докторську дисертацію, після чого був запрошений профресором до Київського університету св. Володимира.

З 1896 р. він брав активну участь в організації Київського політехнічного інституту, де у 1898 р. був призначений професором кафедри фрізики. Декілька років був деканом фрізико-математичного, інженерного, а також хімічного факультетів політехніки, був Головою комісії із створення Зразкового фрізичного кабінету при Педагогічному музеї, побудованому у 1910-1911 рр., викладав також у Київському комерційному інституті, з 1905 по 1917 рр. редагував і видавав журнал “Физическое обозрение”.

У буремні дні осені 1917 р. він виконував обов'язки ректора Університету св. Володимира, а у вересні 1919 р. був обраний ректором КПІ.

У подальші роки він викладав також у Краснодарському політехнічному інституті, Кубанському державному університеті, Київському інституті народної освіти, Київському фармакологічному технікумі, Київському інституті народного господарства тощо.

Останні роки життя (1934-1947) Георгій Георгійович очолював кафедру фізики Київського педагогічного інституту ім. М. Горького (нині Національний педагогічний університет імені М. П. Драгоманова).

За свідченням його біографа, до 1937 року вчений мав 118 публікацій, серед яких - 22 дослідницькі роботи, 11 підручників, 28 статей методикопедагогічного характеру, 38 рецензій на книги і окремі роботи, 7 некрологів, 12 статей до “Физического обозрения".

Життєвий шлях вченого досліджував Юрій Архипович Пасічник, профресор НПУ ім. М.П.Драгоманова, який зробив дуже багато для увічнення його пам'яті [7].

Провідною науковою темою вченого було вивчення природної радіоактивності живих організмів та впливу іонізуючого випромінювання на 
живі об'єкти.

Аналіз його внеску в історію науки і педагогіки здійснили О. П. Майдебура і І. М. Гудков [5].

Його онучки теж продовжили славетний академічний шлях, правда, в інших науках: академік Тетяна Іванівна Заславська (1927-2013) - в економіці й соціології, Майя Іванівна Черемісіна (1924-2013) - лінгвіст, професор Новосибірського державного університету.

Оцифрований архів фонду цих вчених, який містить і колекції сімейних фотографій Де-Метців, а також 5 сканованих видань книг Г.Г. Де-Метца періоду 1892-1919 рр. міститься у Відкритому архіві Сибірського відділення Російської Академії наук [2].

Приватна бібліотека вченого була передана до Наукової бібліотеки його останнього місця роботи. На жаль, вона не зберігалося окремою колекцією, а була влита до основного фонду бібліотеки.

Під час створення електронного каталогу і перегляду фонду de-visu було виявлено 9 видань його книг, 2 відбитки статей 3 наукових журналів та 9 публікацій у журналі “Физическое обозрение”. Належність низки примірників до приватної бібліотеки Де-Метца засвідчує наявність екслібрисів та автографів "Pr. G. De Metz", "G. De Metz", "Georges De Metz" на титульних аркушах та обкладинках, а також дарчі написи вчених, адресованих Георгію Георгійовичу.

Це дає змогу окреслити коло його наукового спілкування, i, сподіваємося, надасть можливість подальшого дослідження особистості Г. Г. Де-Метца у архівах вчених і педагогів, біографічні відомості яких (на жаль, не усіх), нам вдалося відшукати.

Нижче ми наводимо ці написи (бібліографічний опис книжок подається у посиланнях).

Але почнемо з автографа самого Георгія Георгійовича на обкладинці примірника його ранньої роботи, подарованому його матері - Ользі Костянтинівні Травиній: “Моей дорогой маме на память. 26 окт. 1885 г.”.

Піонер польської радіології фрізик Віктор Адольфович Бернацький (1869-1918) подарував Г.Г.Де-Метцу дві книги 3 написами: "Многоуважаемому проф. Г. Г. Де Метцу отъ автора",

Відомий український математик, член АН УРСР, професор Київського університету та Київського політехнічного інституту, засновник і активний діяч Київського математичного товариства Борис Якович Букреєв (1859-1962) залишив на своїх книгах наступні написи: “Дорогому Георгію Георгіевичу

1 Очеркъ аномальной дисперсіи света въ ея фактахъ и теоріяхъ оть начала вопроса и до нашихъ дней : (Написанъ на соисканіе преміи физико-математическаго факультета Императорскаго Новороссійскаго университета и удостоенъ золотой медали) / [Соч.] Г. Г. Де-Метца. Одесса: Типографія “Одесскаго вестника", 1885. [2], 282 с., 5 л. ил. : ил.

2 Курсъ практической физики : Описаніе задачъ, поставленныхъ въ Физической лабораторіи Варшавскаго политехническаго института императора Николая ІІ. Ч. 1. Задачи по общей физике / Преп. В. А. Бернацкій. Варшава : Типо-литографія “Сатурнъ”, 1902. XII, 416 с. : ил. - (в тв. пер.). Написано від руки. Літогр. 
ДеМетцу отъ Б. Букре[ева]"3 та "Дорогому Георгію Георгіевичу Де Метцу на память оть автора", .

Видатний український педагог i методист Микола Миколайович Володкевич (1860-1924), який зробив великий внесок у методику викладання фрізики, на примірнику своєї книги залишив дарчий напис: "Многоуважаемому профрессору Георгію Георгіевичу Де Метцу отъ авторов" 5 .

Російський фрізик, ординарний професор і перший ректор Томського університету Микола Олександрович Гезехус (1845-1918), наукові роботи якого присвячені питанням молекулярної фізики, електрики, оптики, акустики і метеорології, подарував Г. Г. Де-Метцу друге видання підручника з наступним написом: "Многоуважаемому Григорію Григорьевичу Де-Метцу оть автора"6.

Доктор хімії, професор Київського політехнічного інституту Дмитро Костянтинович Добросердов (1876-1936) викладав також у Ветеринарному інституті, Хіміко-фрармацевтичному інституті, а також у Народному університеті - політехнікумі.

"Многоуважаемому Георгію Георгіевичу Де-Метцу XI//13/1913" - його дарчий напис на подарованій книзі ${ }^{7}$.

Петро Олексійович Зілов (1850-1921) зробив значний внесок у розвиток експериментальної фрізики. Протягом 1905-1912 був на посаді попечителя Київського навчального округу. Заснував журнал “Физическое обозрение", організував перший Зразковий фрізичний кабінет, Педагогічний музей у Києві, сільськогосподарські курси для народних вчителів.

Дарчий напис на обкладинці: “Г. Г. Де-Ме[т]цу отъ автора",

Про наступного дарувальника, на жаль, інфрормації не знайдено. $€$ припущення, що він був студентом, якому викладав Г.Г.Де-Метц. “Глубокоуважаемому профрессору Георгію Георгіевичу Де-Метцу от

Введеніе въ теорію рядовъ = Introduction a la theorie des series, par В. Boucreïev, professeur a l'Universite de Kieff. Вып. 1. Ирраціональныя числа. Ансамбли. Функціи. Ряды и произведенія съ постоянными членами : (Лекціи по Введенію въ высшую математику для студентовъ перваго курса) / [Соч.] Б. Я. Букреева, ординарнаго профессора Университета Св. Владиміра. Кіевъ : Тип. Императорскаго Университета Св. Владиміра акціон. о-ва печ. и изд. дела Н. Т. Корчакъ-Новицкаго, 1906. III, 154 с. ; 25 см.

О некоторыхъ частныхъ случаяхъ въ вопросе о maximum и minimum функціи трехъ переменныхъ / [Соч.] Б. Я. Букреева, проф. Университета Св. Владиміра. Москва : Изданіе Московскаго математическаго общества, состоящего при Императорскомъ Московскомъ университете, 1897 (Университетская тип.). 15 с. ; 24 см. Відбиток з вид.: “Математический сборникъ”, Т. 20.

4 Курсъ практической физики : Описаніе задачъ, поставленныхъ въ физической лабораторіи Варшавскаго политехническаго института императора Николая II. Ч. 4. Задачи по электричеству и магнитизму / Преп. В. А. Бернацкій. Варшава : Типо-литографія "Сатурнъ", 1904. VIII, 527 с. : ил. Написано від руки. Літогр.

О практическихъ занятіяхъ по физике : Два доклада, прочитанные на Всероссійскомъ съезде преподавателей физики, химіи и космографіи въ Петрограде въ 1912-13 году / Н. и Н. Володкевичи. Кіевъ : Тип. В. П. Бондаренко и П. Ф. Гнездовскаго, 1915. 32 с. ; 24 см.

6 Основы электричества и магнитизма / Н. А. Гезехусъ. 2-е изд., испр. и доп. С.-Петербургъ : Институть инженеровъ путей сообщенія Императора Александра I, 1907 (Тип. Ю. Н. Эрлихъ). [2], ХІ, 296 с. : рис., табл. ; 27 см. (Сборникъ Института инженеровъ путей сообщенія ... ; вып. 68).

7 Весы и взвешиваніе : Химическіе весы, ихъ теорія, испытаніе и употребленіе : съ 15-ю рис. въ тексте и таблицей / Д. К. Добросердовъ, привать-доценть Казанскаго Университета. Казань : Типо-литографія Императорскаго университета, 1905. VI, 121 с. : рис., табл. ; 26 см.

8 Галилео Галилей : Речь профессора П. А. Зилова, читанная 1 февраля 1893 года въ общемъ собраніи Варшавскаго общества естествоиспытателей. Варшава : Типографія Варшавскаго учебнаго округа, 1893. [2], 45 с., 3 л. ил., портр. 
А. Игнатьева" зазначено на обкладинці 9 .

Автор одного з найкращих дореволюційних шкільних підручників фрізики Федір Миколайович Індріксон (1872-1932) викладав у Полтавській чоловічій гімназії, Полтавській духовній семінарії, Полтавському інституті благородних дівиць, у Петровському Полтавському кадетському корпусі, потім у СанктПетербурзькій гімназії Майера. Після евакуації до Харбіну працював у місцевому Педінституті і російських школах.

“Глубокоуважаемому Георгію Георгіевичу Де-Метцу от автора" 10 та “Глубокоуважаемому Георгію Георгіевичу де Метцу от автора. Окт. 1913"11 його автографи на титульному аркуші і обкладинці двох книжок.

Станіслав Йосипович Каляндик - випускник фрізико-математичного факультету Київського університету (1908). У 1912-1914рр. знаходився у закордонному відрядженні (Англія, Німеччина). Профресор Київського і Кам'янець-Подільського університетів. У 1919-1920 рр. - екстраординарний професор кафедри фрізики Таврійського університету. На жаль, більше інформації про нього нам знайти не вдалося.

"Глубокоуважаемому Профессору Георгію Георгіевичу Де Метцу от автора. 27.IV.18" - значиться на титульному аркуші його книги ${ }^{12}$.

Заслужений професор, один 3 найвидатніших учених-механіків, талановитий інженер і педагог, організатор вищої технічної освіти та відомий громадський діяч, засновник і перший директор Харківського технологічного інституту (1885-1898), засновник і перший директор Київського політехнічного інституту (1898-1902) Віктор Львович Кирпичов (1845-1913) залишив наступний напис на обкладинці: "Многоуважаемому Георгію Георгіевичу де Метцъ отъ В. Кирпичева"13.

Олександр Вікентійович Клосовський (1846-1917) - перший український метеоролог-геофізик, доктор фрізичної географії, профресор, членкореспондент Петербурзької академії наук.

Закінчив курс фрізико-математичного фракультету Київського університету св. Володимира у 1868 році. 31876 р. - приват-доцент того ж університету. Читав лекції з метеорології та фрізичної географії. Викладав також у Новоросійському університеті (нині - Одеський національний університет імені І. І. Мечникова) і (з 1905 р.) - у Санкт-Петербурзькому університеті.

"Многоуважаемому Георгію Георгіевичу де-Метцу. А. Клоссовскій” -

9 Изследованіе гидродиффузіи помощью спектрофотометра / Ст. Ан. Игнатьевъ. Одесса : “Экономическая” тип., 1906. [2], 42 с. : ил. ; 25 см.

10 Работы по физике для средней школы / Ф. Н. Индриксонъ. 2-е изд., испр. и знач. доп. Санкт-Петербургъ : Изданіе А. С. Суворина, 1911 (Тип. А. С. Суворина). VI, [2], 256 с. : рис., табл. ; 21 см.

11 Сокращенный учебникь физики / Ф. Н. Индриксонъ. Санкт-Петербургъ : Тип. А. С. Суворина "Новое Время”, 1914. Х, 480 с., 1 л. ил. : ил., табл. ; 24 см.

12 Электрическія свойства нагретыхъ газовъ и паровъ / С. І. Каляндыкъ $=$ On the electrical properties of heated gases and vapours / by S. J. Kalandyk. Кіевъ : Типографія Университета Св. Владиміра Акц. О-ва печ. и изд. дела Н. Т. Корчакъ-Новицкаго, 1917. 139 с. : черт. ; 25 см. На обкл. дата: 1918.

13 Значеніе фантазіи для инженеровъ [Текст] / [Соч.] В. Л. Кирпичева. Кіевъ: Тип. С. В. Кульженко, 1903. 21 c. $; 25$ cM. 
зазначено на обкладинці його книги ${ }^{14}$.

Український і російський хімік, заслужений діяч науки і техніки РРФСР, Яків Іванович Михайленко (1864-1943) закінчив Київський університет у 1888 році. 31901 р. - профресор, завідувач кафедрою загальної і аналітичної хімії у Томському технологічному інституті. $€$ автором 15 навчальних посібників із загальної і неорганічної хімії.

На титульному аркуші подарованої книги: "Многоуважаемому Георгию Георгиевичу Дэметцу. Я. Михайленко. Кіев. 4 ян. 1906”"15.

“Многоуважаемому профессору Георгію Георгіевичу Де-Метцу от автора. В. Попов. СПб. Загородный 76" [далі нерозбірливо] - дарчий напис на титульному аркуші книги Василя Івановича Попова (1872-?), інформацію про життя і діяльність якого нам теж не вдалося знайти ${ }^{16}$.

Сергій Миколайович Реформатський (1860-1934) - видатний хімікорганік, організатор кафедри органічної хімії КПІ і її перший завідуючий, засновник Київської школи хіміків-органіків, член-кореспондент Академії наук СРСР (1928). 31891 по 1934 рік - професор Київського університету, автор понад 50 наукових праць та підручника "Начальный курс органической химии" (з 1893 року витримав 17 видань). Дарчий напис перед текстом: "Многоуважаемому Георгію Георгіевичу Де-Метцу оть автора"17.

Валентин Львович Розенберг зробив напис на титульному аркуші своєї книги: “Многоуважаемому Георгію Георгіевичу де-Метцу от автора", 18.

Олександр Васильович Сперанський (1865-1919) - хімік, профресор. Викладав з 1892 у Московському університеті. Переїхавши до Києва, розпочав роботу в Київському університеті, назавжди увійшовши в історію цього навчального закладу як засновник кафедри фізичної хімії. Першим в Російській імперії почав викладати аналітичну хімію, що базувалася на основах фрізичної хімії. Працюючи зі студентством, створив кілька підручників, які потім багаторазово перевидавалися. На титульному аркуші книги міститься напис: "Многоуважаемому Георгию Георгіевичу Де Метцъ отъ автора"19.

Петро Іванович Холодний (1876-1930) - український державний,

14 Метеорологическое обозреніе [Текст]: (Труды метеорологической сети юго-запада Россіи въ 1889 году) / [Соч.] А. Клоссовскаго, профессора императорскаго Новороссійскаго университета. Одесса : Экономическая типографія, 1890. [4], IV, 192 с., 4 л. ил. : ил. (в м. пер.). Из 51 т. “Зап. Новорос. ун-та”.

15 Къ вопросу о соотношеніи между парциальной плотностію растворителя въ растворе и упругостію пара раствора [Текст] / Изследованіе Я. И. Михайленко. - Кіевъ : Лито-типографія И. И. Чоколова, 1905. [4], 252, [1] с. : табл. Приложеніе къ кн. 4 "Известій Томскаго технологическаго института имп. Николая II“. - Деф.: відсутні с. 33-252.

16 Самодельные приборы и значеніе ихъ для преподаванія физики [Текст]: Съ приложеніемъ списка упрощенныхъ приборовъ, изготовляемыхъ авторомъ въ г. Либаве, коммерческое училище О. Ф. Чинка / В. И. Поповъ. Москва : Т-во И. Д. Сытина, 1910. 44 с. : табл., рис. ; 22 см.

17 Матеріалы для исторіи химической лабораторіи университета св. Владиміра /[Соч.] Проф. С. Н. Реформатскаго. [Москва] : [Товарищество типографіи А. И. Мамонтова], [1899?]. 29 с. ; 25 см.

18 Первые уроки физики въ простомъ изложеніи (введеніе въ физику) : Беседы объ основныхъ свойствах вещества для школь и самостоятельнаго чтенія лицамъ безъ подготовки (съ методическими указаніями преподавателямъ) : Изъ школьной практики / В. Л. Розенбергъ. 2-е изд., испр. и доп. С.-Петербургъ : [б. и.], 1913 (Тип. В. Безобразовъ и Ко (Вл. Н. П. Зандманъ)). XIV, 114, [1] с. : ил. ; 23 см.

19 Изследованіе упругости паровъ насыщенныхъ растворовъ / А. Сперанскій. Кіевъ : Тип. И. И. Чоколова, 1910. [4], 101 с. : ил. ; 25 см. 
громадський діяч, член Української Центральної Ради, міністр народної освіти Української Народної Республіки, художник, учений-хімік. Після закінчення у 1897 р. природознавчого факультету Київського університету за спеціальністю математика та мінералогія викладав (з 1898 р.) у Київській Технічній школі на кафедрі фрізики.

“Многоуважаемому Георгію Георгіевичу Де-Метцу отъ автора" зазначено перед текстом його статті ${ }^{20}$.

Автор дуже популярних у 1920-1930-ті роки підручників з фрізики для школи, російський фрізик і педагог Олександр Васильович Цингер (18701934) викладав на медичному фракультеті Московського університету, на курсах Московського товариства виховательок і вчительок, на Московських вищих жіночих курсах; на початку 1900-х років він очолював кафедру фізики в Комерційному інституті, був засновником першого російського методичного журналу “Фізика”, що видавався з 1912 року по 1916 рік.

Залишив дарчий напис "Глубокоуважаемому Георгію Георгіевичу ДеМетцу. От составителя" на титульному аркуші задачника ${ }^{21}$.

Хімік-органік і інженер-хімік, член Академії наук Української РСР Володимир Георгійович Шапошников (1870-1952) у 1898 році був запрошений професором до Київського політехнічного інституту, на кафедру хімічної технології, по відділу фарбувальних і волокнистих речовин. 31928 році очолював лабораторію у Київському інституті народного господарства.

Головні наукові праці вченого стосувалися технології природних волокон і хімії барвників. На подарованому примірнику своєї книги залишив напис: "Многоуважаемому Георгію Георгіевичу Де-Метцу оть автора"22.

Польський фрізико-хімік, член Польської академії наук Богдан Андрійович Шишковський (1873-1931) закінчив Київський університет у 1896 р., працював там же з 1907 р. У 1916-1919 рр. - ректор Польського університетського колегіуму в Києві. 31920 р. - професор Ягеллонського університету в Кракові. Основні праці Шишковського стосуються області колоїдної хімії та теорії розчинів.

Дарчий напис "Георгію Георгіевичу Де-Метцу отъ автора" міститься на титульному аркуші ${ }^{23}$.

Свою першу роботу про спектр рентгенівського випромінювання Матвій Петрович Бронштейн опублікував у відомому німецькому фрізичному журналі

20 Коллоидальный селенъ / [Соч.] П. И. Холоднаго. [Б. м. : б. и.], [190-?]. 128-142, 17-19, [1] с. (Физическій отделъ. Отдель первый). У надзаг. дан.: Томъ ХХХVIII. Выпускъ 3.

21 Задачи и вопросы по физике : Закладка-масштабъ: 4 таблицы и 180 рис. въ тексте / А. В. Цингеръ, преподаватель Московскаго коммерческаго института и коммерческихъ училищъ Московскаго общества распространенія коммерческаго образованія. Москва : Типографія В. М. Саблина, 1913. 295, 11 с. : ил., табл. ; $21 \mathrm{cм.}$

22 Къ вопросу о четырех-летнемъ курсе на химическихъ отделеніяхъ политехническихъ институтовъ : (Изъ матеріаловъ по вопросамъ высшаго химико-техническаго образованія) / Проф. В. Г. Шапошниковъ. Кіевъ : Тип. С. В. Кульженко, 1910. 30 с. Оттискь из "Известій Киевскаго политехническаго института императора Александра II".

23 Примененіе теоріи строенія атомовъ и молекуль Дж. Дж. Томсона къ химіи / Богданъ Шишковскій, профессоръ Польскаго университетскаго коллегіума въ Кіеве, приватъ-доценть Университета св. Владиміра. Кіевъ : Типографія Т-ва И. Н. Кушнеревъ и Ко, 1918. VI, 248 с. : табл. 
у дев'ятнадцятилітньому віці, коли навчався у електромеханічному технікумі.

Ставши у 1926 році студентом першого курсу Ленінградського державного університету, він був автором вже шести статей з квантової механіки. У 1935 році захистив докторську дисертацію на тему про квантування гравітаційного поля. Його автограф "Многоуважаемому проф. Георгию Георгиевичу Де-Метцу от автора. Киев 30 июня 1926" міститься на титульному аркуші статті ${ }^{24}$.

Також нам не вдалося віднайти будь-якої інформації, окрім року народження (1881) про життя і діяльність Костянтина Домбровського, який залишив дарчий напис "Многоуважаемому Георгію Георгіевичу Де Метцъ от автора" на титульному аркуші дисертації ${ }^{25}$.

Німецький педагог і фрізик Карл Ернст Генріх Грімзель (1861-1914) у 1909 році опублікував підручник з фрізики, який неодноразово перевидавався не тільки у Німеччині, але й у Росії, Англії, і навіть у Китаї. Крім цього, російською мовою було перекладено його наступні книжки: "Дидактика и методика ффизики в средней школе” (1913), “Избранные работы по фризике для учеников средней школы" (1914).

Лист професора Грімзеля до Г.Г.Де-Метца на окремому аркуші німецькою мовою від 22/3 1907 р. міститься у його книзі 1906 року видання ${ }^{26}$.

Винахідник нового типу рентгенівської трубки український біофрізик Олександр Миколайович Яницький (1871-1943) закінчив фрізикоматематичний фракультет Київського університету у 1895 році. Працював асистентом Київського політехнічного інституту, вчителем ффізики у Колегії Павла Ґалаґана. У 1919-1920 роках - приват-доцент кафедри фрізики Українського університету в Кам'янці-Подільському. 31920 року Яницький у еміграції в Німеччині, працював асистентом Інституту біофрізики у Франкфуртіна-Майні. Наукові праці стосуються біологічної дії іонізованого повітря, радіоактивних речовин та рентгенівських променів.

На титульному аркуші відбитку його статті дарчий напис: "Учителю моему высокоуважаемому Георгію Георгіевичу Де-Метцу признательный автор. 23.2 [19]25 Франкфурт на Майне"27.

Український фрізик, кандидат фрізико-математичних наук Володимир Всеволодович Кондогурі (1890-1944) викладав у Одесі в жіночих гімназіях, Реальному училищі, у середніх школах, на вечірніх курсах тощо. У 1929-31 рр. асистент, завідуючий фізичною лабораторією фрізико-газового відділу Українського наукового-дослідного хіміко-радіологічного інституту. Вивчав вплив радіоактивного випромінювання, електричного і магнітного полів на

24 Zur Theorie der Feinstruktur der Spektrallinien / M. Bronstein. Berlin : Verlag von Julius Springer, 1926. 217-224 S.; $23 \mathrm{~cm}$. Zeitschrift für Physik. Sonderabdruck. Band 37, Heft 3.

25 Über die Einwirkung der verschiedenen Stoffe, insbesondere des Wasserstoffsuperoxyds auf die photographische Platte : Inaugural-Dissertation zur Erlangung der Doctorwürde der hohen philosophischen Fakultät der Unuversität Leipzig / vorgelegt von Constantin Dombrowsky aus Moskau (Rußland). Borna ; Leipzig : Buchdruckerei Robert Noske, 1908. [8], 68 S. : il.

26 Ausgewählte physikalische Schülerübungen : Beilage zum Bericht über das Schuljahr 1905/1906 / von Prof. E. Grimsehl ; Oberrealschule auf der Uhlenhorst zu Hamburg. Hamburg : Gedruckt bei Lütcke \& Wulff, E. H. Senates, wie auch des Johanneums Buchdruckern, 1906. 42 S. : il. ; $25 \mathrm{~cm}$.

27 Über die Bedeutung des Gasgehalts von Metallen für einige elektrische Erscheinungen / Alexander Janitzky. Berlin : Verlag von Julius Springer, 1925. 277-299 S. ; 23 cm. Zeitschrift für Physik. Sonderabdruck Band 31, Heft 1/4. 
кристалізацію переохолоджених рідких діелектриків.

На титульному аркуші відбитку його статті - "Многоуважаемому Георг. Георг. проф. Де Метцу от автора" ${ }^{28}$.

Доктор математичних наук, профресор Інституту народної освіти в Києві, член математичних товариств (Київ, Палермо), співробітник Комісії чистої математики Академії Наук Максим Каленикович Куренський (1895-1940) закінчив Університет св. Володимира у 1918 р. Основні праці 3 диференціальних рівнянь і застосування в диференціальній геометрії теорії пружностей, математичних проблем механіки.

На обкладинці відбитку статті дарчий напис: “Глубокоуважаемому Георгію Георгіевичу Де-Метцу. 17/IV 1931”29.

Український фізіолог і гістолог, Академік АН УРСР, Заслужений діяч науки УРСР Олександр Васильович Леонтович (1869-1943) закінчив медичний факультет Київського університету у 1893 році. У 1900 р. захистив докторську дисертацію. Працював у Київському університеті, Київському політехнічному інституті, Інституті клінічної фрізіології АН України. Основні наукові роботи стосуються фрізіології та гістології периферійної нервової системи.

На обкладинці відбитку статті дарчий напис “Отъ автора" 30 .

Борис Миколайович Раєвський (1893-1974) - український і німецький науковець-біофрізик. Навчався у 1912-1917 роках у Київському університеті. До 1920 року - старший асистент Київського університету. Згодом у еміграції.

Працював професором біофізики у Франкфуртському університеті, директором Інституту біофізики Товариства ім. Макса Планка у Франкфурті-наМайні, який було створено за його ініціативи. Як фрізик-дослідник Раєвський зробив вагомий внесок у дослідження біологічних наслідків опромінення та встановлення радіаційних стандартів охорони здоров'я.

Праці і винаходи вченого відносяться до радіології, радіобіології, біофізики високих частот і надзвуків. Біофізичний інститут у Саарбрюккені названо його ім'ям.

У фонді Бібіліотеки знайдено два відбитки статей з дарчими написами від Бориса Миколайовича: “Съ глубокимъ уваженьемъ отъ автора" 31 та "Дорогому учителю Георгію Георгіевичу Де Метцу съ глубокимъ уваженіемъ. Б. Раевскій

28 Einfluß des elektrischen und magnetischen Feldes auf die Kristallisation unterkühlter Flüssigkeiten / W. Kondoguri. Berlin : Verlag von Julius Springer, 1928. 589-601 S. ; 23 cm. Zeitschrift für Physik. Sonderabdruck 47. Band, 7. und 8. Heft.

29 Zur Integrabilitätsmethode partieller Differentialgleichungen erster Ordnung mit zwei abhängigen und zwei unabhängigen Veränderlichen / von M. Kurenskyj (Kiew). Palermo : Tipografia matamatica G. Senatore, 1931. 8 S. $25 \mathrm{~cm}$. Estratto dal tomo LV (1931 Rendiconti del Circolo Matematico di Palermo. Adunanza del 24 Novembre 1929: 121-128.

30 Aus welchem Gräsern stellt man Strohschreibhebel am besten her? / A. Leontowitsch, Privat-Dozent der Kiewer Universität. Strassburg : Verlag von Karl J. Trübner, 1909. 304-305 S. ; 24 cm. (Notizen aus der Arbeits- und Lehrpraxis). Sonderabdruck aus Band I der Zeitschrift für biologische Technik und Methodik.

31 Über den Abschwächungskoeffizienten von Wasser und Aluminium bei harten Röntgenstrahlen / E. Lorenz und B. Rajewsky ; Aus dem Institut für physikalische Grundlagen der Medizin, Frankfurt a. M. Frankfurt a. M. : [s. n.], 1928. 475-486 S. : il. ; 25 cm. Sonderabdruck aus "Strahlentherapie", Band XVI (1924). 
25-III-25 Frankfurt/M." ${ }^{32}$.

Оскар Єгорович Луц (1871-?) - ад'юнкт-профресор аналітичної хімії Ризького політехнічного інституту, доктор філософрії. Закінчив Ризьке політехнічне училище, захистив дисертацію у 1899 р. і отримав ступінь доктора фрілософрії Ризького університету. У 1908 р. захистив дисертацію у Київському університеті Св. Володимира і отримав ступінь магістра хімії.

На обкладинці відбитку його статті дарчий напис: "Глубокоуважаемому Георгію Георгіевичу Де Метцъ отъ автора"з3.

Вчений-електротехнік, профресор Інституту інженерів шляхів сполучення Генріх Карлович Мерчинг (1860-1916) закінчив фрізико-математичний фракультет Варшавського університету і Санкт-Петербурзький Інститут шляхів сполучення. 31888 по 1893 рр. був також першим викладачем електротехніки у Санкт-Петербурзькому електротехнічному інституті.

На обкладинці відбитку його статті дарчий напис: "Многоуважаемому профрессору Г. Г. Деметцу отъ автора" ${ }^{34}$.

Математик, доктор фрізико-математичних наук, член-кореспондент АН УРСР Євген Якович Ремез (1896-1975) закінчив Київський інститут народної освіти.

У 1928-55 рр. викладав у Педагогічному інституті й інших вишах у Києві; 3 1934 р. працював у Інституті математики АН УРСР, член редколегії “Українського математичного журналу”. Автор понад 100 праць, основні з яких стосуються конструктивної теорії функцій та наближеного аналізу.

Перед текстом відбитку його статті напис: "Профрессору Георгию Георгиевичу Де Метцу с глубоким уважением от автора. 25.V. 1937”35.

Польський астроном і геофізик, член Краківської АН Маврикій Рудзький (1862-1916) розпочинав навчання у Львівському університеті, у 1886 р. закінчив фрілософрське відділення Віденського університету і отримав ступінь доктора. Професор Краківського університету (1901) і директор університетської обсерваторії (1902). Автор близько 150 праць з теоретичної астрономії, сейсмології, метеорології.

Дарчий напис: “Дорогому Г.Г.Де Метцу оть автора” перед текстом відбитку його статті ${ }^{36}$.

Рафаїл Миколайович Савельєв (1851-1903) - інженер, раціоналізатор і метеоролог; професор геодезії Київського політехнічного інституту. Закінчив

32 Zur frage der Qualifizierung von Röntgenstrahlen / E. Lorenz und B. Rajewsky ; Aus dem Universitätsinstitut für physikalische Grundlagen der Medizin, Frankfurt a. M. Frankfurt a. M. : [s. n.], [1925]. 349-357 S. : il. ; 24 cm. Sonderabdruck aus "Strahlentherapie", Band XIX (1925).

33 Ueber die optisch-isomeren Benzylmalamidsäuren / O. Lutz. Berlin : Buchdruckerei A. W. Schade, 1904. 2123-2129 S. ; $24 \mathrm{~cm}$. Sonderabdruck: Berichte der deutschen chemischen Gesellschaft, Jahrgang 37, Heft 9 (März/Mai 1904): 2123-2129.

34 Studien über das elektrische Spektrum im Gebiete sehr kurzer Wellen [Текст] / von H. Merczyng. - Cracovie : Imprimerie de l'Université, 1910. [2], 101-115 p., 2 Pl. ; 25 cm. Extrait du Bulletin de l'Académie des Sciences de Cracovie, Classe des Sciences Mathématiques et Naturelles. Série A: Sciences mathématiques. Avril 1910.

35 Sur l'interpolation des fonctions qui sont d'allure irrégulière dans l'intervalle donné / par E. Rémès ; Журнал Інституту математики Академії наук УРСР = Journal de l'Insitut mathématique de l'Académie des sciences de la RSS d'Ukraine. [Київ] : [s. n.], 1937. 9-51 р. ; 26 cm.

36 Sur la détermination de la figure de la terre d'après les mesures de gravité / par. M. P. Rudzki. - Paris : Imprimerie Gauthier-Villars, [1905]. 28 S. ; 26 cm. Extrait du Bulletin astronomique; février 1905. 
курс в Санкт-Петербурзькому Інституті інженерів шляхів сполучення у 1872 р. і до 1895 р. працював за фрахом на залізниці. У 1898 році отримав посаду профресора Київського політехнічного інституту на кафедрі геодезії. 31883 року Савельєв захоплено займався метеорологією, і з цією метою заснував станцію у Москві. 31888 по 1895 рік багато часу приділив вивченню сонячної активності; про результати цих досліджень випустив у Києві низку публікацій.

Цікаво, що стаття, відтиск якої фрранцузькою мовою подарований ДеМетцу, був опублікований також російською мовою цього ж року в “Журнале русского ффизико-химического общества при Санкт-Петербургском университете", відтиск з якого вийшов з друку у типографії В. Демакова у Санкт-Петербурзі - “О точности актинометрических наблюдений”.

Дарчий напис перед текстом статті: "Многоуважаемому Георгію Георгіевичу де-Метцъ отъ автора"37.

Український ффізик, фрілософф природознавства, завідувач кафедри теоретичної фрізики Київського університету Лев Якович Штрум (1890-1936) у 1908 році поступив до математичного фракультету Петербурзького університету. Виконав дипломну роботу "Математична теорія рентгенівських променів" і був залишений при університеті як професорський стипендіат, але не затверджений через політичні причини. Через це переїхав до Києва, де прослухав повний курс механічного фракультету КПІ. 3 листопада 1921 року його призначають науковим співробітником ВУАН. Паралельно з 1922 року вчений зарахований аспірантом на науково-дослідну кафедру фізики КП।; 3 жовтня 1925 року він стає їі науковим співробітником. У 1926 році він стає профресором фізики, а у 1927 - захищає докторську дисертацію "Теорія квант і рентгенівське випромінення”. Досліджував проблеми руху на швидкостях більше за швидкість світла в рамках теорії відносності. Автор більш ніж 50 наукових робіт з фрізики українською, російською, німецькою мовами.

На титульному аркуші відбитку статті напис: "Глубоко уважаемому проф. Георгию Георгиевичу де-Мецу от автора. 10/V [19]25"38.

Петро Савич Тартаковський (1895-1940) - фрізик, доктор фрізикоматематичних наук. У 1918 р. закінчив Київський університет, де і продовжив працювати. У 1925-29рр. - завідуючий лабораторією ЛФТІ і професор Ленінградського політехнічного інституту. 1929 р. переїхав до Томська для участі у створенні Сибірського фрізико-технічного інституту. Завідуючий лабораторією електронних явищ (1929-1937), відділом теоретичної фрізики (1930-1937) Томського університету. Створив і очолив у ТГУ кафедру теоретичної фрізики. У 1937-1940 рр. завідував кафедрою фрізики у Ленінградському педагогічному інституті ім. О. І. Герцена і кафедрою технічної електроніки Ленінградського політехнічного інституту. Зробив у 1927 р. вагомий внесок в експериментальне обґрунтування хвильових властивостей

\footnotetext{
37 Sur le degré de précision que l'on peut atteindre dans les observations actinométriques / par M. R. Savélief. Paris : Imp. Gauthier-Villars et Fils, 1893. 22 p. : ill. ; 23 cm. Extrait des Annales de Chimie et de Physique, 6e serie, t. XXVIII; mars 1893.

38 Zur Theorie des Strahlungsgleichgewichts / L. Strum. Berlin : Verlag von Julius Springer, 1925. 866-868 S. ; 23 cm. Zeitschrift für Physik. Sonderabdruck Band 31, Heft 11.
} 
електрона. Результати його експериментів увійшли до підручників фрізики і фрілософії й вплинули на світогляд людей XX ст.

Дарчий напис: "Глубокоуважаемому Георгию Георгиевичу Де-Метцу от автора. 10.VI. 1924." 39.

Скановані дарчі написи, титульні сторінки або обкладинки видань, на яких вони містяться, разом із біографічними даними вчених, які їх залишили, доступні у віртуальній виставці, підготовленій співробітниками відділу рідкісних видань та представленій у репозитарії Наукової бібліотеки національного педагогічного університету імені М. П. Драгоманова [1].

\section{Використана література:}

1. Книги з бібліотеки Г. Г. Де-Метца у фондах Наукової бібліотеки НПУ ім. М. П. Драгоманова : віртуальна виставка відділу рідкісних і цінних видань, доповнена біографічними відомостями вчених, які залишили автографи на подарованих Г.Г. Де-Метцу публікаціях. URL: http://lib.npu.edu.ua/new-collections/uploads/objects/363/pdf/metz_2.pdf (дата звернення: 13.03.2019).

2. Коллекции фонда Т. И. Заславской - М. И. Черемисиной. URL: http://odasib.ru/openarchive/ Portrait.cshtml?id=Xc_furs_634919475472910156_2069 (дата звернення: 13.03.2019).

3. Кусий Леся. Бібліотеки українських діячів як джерело формування фонду концентрації львівської філії бібліотеки АН УРCP (1940-1944). URL: http://www.lsl.lviv.ua/wpcontent/uploads/Z/Z2014/JRN/PDF/27.pdf (дата звернення: 13.03.2019).

4. Лісова І. В. “Приватна книжкова колекція”: теоретичні підходи до визначення поняття українська культура: минуле, сучасне, шляхи розвитку: Наукові записки Рівненського державного гуманітарного університету. 2012. Вип. 18. Том II. URL: file:///C:/Users/luda/Downloads/ Uk_msshr_2012_18(2)_58\%20(1).pdf (дата звернення: 13.03.2019).

5. Майдебура О. П., Гудков I. М. Видатний фізик, організатор вищої освіти і науки Г. Г. Де-Метц перший дослідник в Україні з дії рентгенівських променів і природної радіоактивності на живі організми. URL: http://nd.nubip.edu.ua/2012_4/12mop.pdf (дата звернення: 13.03.2019).

6. Палій Оксана. Мандрівка за горизонт : до історії формування фонду спеціальних колекцій Центру Шептицького український католицький університет URL: https:/ucu.edu.ua/news/mandrivka-zagoryzont-istoriyi-formuvannya-fondu-spetsiyalnyh-kolektsij-tsentru-sheptytskogo/ (дата звернення: 13.03.2019).

7. Пасічник Ю. Георгій Георгійович Де-Метц - фізик, педагог, організатор (до 150-річчя 3 дня народження заслуженого професора фізики). Наукові записки НДУ ім. М. Гоголя. Психологопедагогічні науки. 2011. № 7. С. 181-185.

8. Пасічник Ю. Георгій Георгійович Де-Метц - фізик, педагог, організатор : До 150-річчя від дня народження. Фізика та астрономія в школі. 2011. №5. С. 42-47.

\section{References:}

[1] Knyhy z biblioteky H. H. De-Mettsa u fondakh Naukovoi biblioteky NPU im. M. P. Drahomanova : virtualna vystavka viddilu ridkisnykh i tsinnykh vydan, dopovnena biohrafichnymy vidomostiamy vchenykh, yaki zalyshyly avtohrafy na podarovanykh $H$. H. De-Mettsu publikatsiiakh. URL: http://lib.npu.edu.ua/new-collections/uploads/objects/363/pdf/metz_2.pdf (data zvernennia: 13.03.2019).

[2] Kollektsyy fonda T. Y. Zaslavskoi - M. Y. Cheremysynoi. URL: http://odasib.ru/openarchive/ Portrait.cshtml?id=Xc_furs_634919475472910156_2069 (data zvernennia: 13.03.2019).

[3] Kusyi Lesia. Biblioteky ukrainskykh diiachiv yak dzherelo formuvannia fondu kontsentratsii lvivskoi filii biblioteky AN URSR (1940-1944). URL: http://www.lsl.lviv.ua/wp-content/uploads/Z/Z2014/ JRN/PDF/27.pdf (data zvernennia: 13.03.2019).

[4] Lisova I. V. "Pryvatna knyzhkova kolektsiia": teoretychni pidkhody do vyznachennia poniattia ukrainska kultura: mynule, suchasne, shliakhy rozvytku: Naukovi zapysky Rivnenskoho derzhavnoho humanitarnoho universytetu. 2012. Vyp. 18. Tom II. URL: file://C:/Users/luda/Downloads/ Uk_msshr_2012_18(2)_58\%20(1).pdf (data zvernennia: 13.03.2019).

39 Zur Theorie der Bandenspektra [Text] / P. Tartakowsky. Braunschweig : Friedr. Vieweg und sohn ; Berlin : Julius Springer, 1924. 98-116 S.; 23 cm. Zeitschrift für Physik. Sonderabdruck Band 24, Heft 2. 
[5] Maidebura O. P., Hudkov I. M. Vydatnyi fizyk, orhanizator vyshchoi osvity i nauky H. H. De-Metts pershyi doslidnyk $\mathrm{v}$ Ukraini $\mathrm{z}$ dii renthenivskykh promeniv i pryrodnoi radioaktyvnosti na zhyvi orhanizmy. URL: http://nd.nubip.edu.ua/2012_4/12mop.pdf (data zvernennia: 13.03.2019).

[6] Palii Oksana. Mandrivka za horyzont : do istorii formuvannia fondu spetsialnykh kolektsii Tsentru Sheptytskoho ukrainskyi katolytskyi universytet URL: https:/ucu.edu.ua/news/mandrivka-za-goryzontistoriyi-formuvannya-fondu-spetsiyalnyh-kolektsij-tsentru-sheptytskogo/ (data zvernennia: 13.03.2019).

[7] Pasichnyk Yu. Heorhii Heorhiiovych De-Metts - fizyk, pedahoh, orhanizator (do 150-richchia z dnia narodzhennia zasluzhenoho profesora fizyky). Naukovi zapysky NDU im. M. Hoholia. Psykholohopedahohichni nauky. 2011. № 7. S. 181185.

[8] Pasichnyk Yu. Heorhii Heorhiiovych De-Metts - fizyk, pedahoh, orhanizator : Do 150-richchia vid dnia narodzhennia. Fizyka ta astronomiia v shkoli. 2011. № 5. S. 42-47.

САВЕНКОВА Л. В., ТоРЛИНИ. Частная библиотека учёного как дополнительный источник воссоздания его творческой биографии.

Исследование научного наследства ученых является важным составляющей изучения истории любого университета. В подготовленном материале представленные результать исследования личного собрания известного физика, профессора, главы кафедры физики Киевского педагогического института имени М. Горького с 1934 до 1947 года Г. Г. Де-Метиа, которые позволяют отследить научные связи ученого в первой половине 20-го века.

Ключевые слова: исследование, источники, наука, история, жизненный путь.

SAVENKoVA LIUDMYLA, ToRLIN IGOR. Private library of scientist as additional source of recreation of his creative biography.

Research of scientific inheritance of scientists is important making the studies of history of any university. In geared-up material the presented results of research of the personal collection of the known physicist, professor, head of department of physics of the Kyiv pedagogical college of the name of M. of Gorki from 1934 to 1947 Дe-Memųa, which allow to watch scientific connections of scientist in the first half of 20th century.

Keywords: research, sources, science, history, course of life.

DOI: https://doi.org/10.31392/NZ-npu-145.2019.21

УДК 378.018.43:62/69-029:004

Слабко В. М., Запольська Ю. А.

\section{НАВЧАЛЬНІ БЛОГИ ЯК ІНСТРУМЕНТ ДИСТАНЦІЙНОЇ ФОРМИ НАВЧАННЯ У ФОРМУВАННІ ПРОФЕСІЙНОЇ ІНШОМОВНОЇ КОМПЕТЕНТНОСТІ СТУДЕНТІВ ІНЖЕНЕРНО-ТЕХНІЧНИХ СПЕЦІАЛЬНОСТЕЙ}

Однією із найскладніших та гострих педагогічних проблем іншомовної підготовки студентів інженерно-технічних закладів вищої освіти загалом є забезпечення індивідуалізації навчання і стимулювання мотивації студентів до саморозвитку. На думку автора статті, можливим дієвим засобом вирімення иих проблем у дистаниійній формі навчання $\epsilon$ використання технології ведення навчальних блогів. Авторська методика ведення блогу частково схожа з проектним методом і методом “портфоліо”. 3 одного боку, навчальний блог доцільно розглядати як проект: його створення і регулярне наповнення вимагає прагматичної 